\title{
Promega, Roche clash over use of Taq in labs
}

San Francisco. More than 150 researchers from institutions across the United States have been dragged unwittingly into the legal battle between Hoffman-LaRoche and Promega Corporation over the rights to sell the thermostable enzyme Taq polymerase.

In court papers filed in US District Court in San Francisco on 15 May, Roche and its subsidiary Roche Molecular Systems Inc. of New Jersey identify the scientists as having "infringed" its patent on the enzyme by using an unauthorized Taq, produced by Promega, for experiments using polymerase chain reaction (PCR) techniques.

The list was drawn up by Roche at the court's direction as part of a suit which it filed two years ago against Promega, claiming that the latter company had broken an agreement not to sell its own Taq to scientists for use in PCR, the rights to which Roche purchased from Cetus in 1992 at a cost of $\$ 300$ million.

William Linton, president and chief exec- utive officer of Promega, claims that listing the scientists represents an attempt by Roche to "exert control over US science and intimidate and direct huge profits from American scientists and their institutions".

But Kathy Ordonez, president of Roche Molecular Systems in Branchburg, New Jersey, said the company does not intend to involve the scientists listed in any litigation. "The issue before us is to resolve the matter with Promega," says Ordonez, describing Promega's attempts to stir up concern in the scientific community as "unethical".

Roche's list identifies scientists from institutions such as the Scripps Research Institute, the University of California, the Howard Hughes Medical Institute and the National Cancer Institute who have acknowledged in published papers that they have used the Promega enzyme in PCR.

Promega says that accusing those on the list of infringing the patents on Taq challenges US patent law and practice "which

\section{Gallo to set up shop in Baltimore}

Baltimore. After a year-long courtship involving as many as eight suitors, AIDS researcher Robert Gallo has decided to end his 30-year association with the US National Cancer Institute $(\mathrm{NCl})$ to head a new Institute of Human Virology at the University of Maryland in Baltimore. $\mathrm{He}$ will be joined by William Blattner, a fellow $\mathrm{NCl}$ researcher and epidemiologist, and Robert Redfield, a clinician at the Walter Reed Army Institute of Research.

The new institute is expected to open early in the autumn, and will take a multidisciplinary approach to the study of chronic viral diseases, with a major emphasis on HIV-1 and AIDS research. In addition to serving as director of the institute, Gallo will head its basic sciences division, while Redfield will lead the clinical division, and Blattner head the division of epidemiology and prevention.

The institute will be housed in the 200,000-square-foot Maryland Biotechnology Center, and will eventually have 300 employees. A private biotechnology company linked to the institute will also be set up, but neither Gallo, Redfield, nor Blattner will be officers in the company.

In addition to funds from the University of Maryland, the institute will receive $\$ 12$ million during its first three years from the state of Maryland and the city of Baltimore.

The financial package was not the largest offered among three other institutes that were wooing the trio - namely the Medical College of Pennsylvania in Philadelphia, the Virginia Commonwealth

University in Richmond, and the University of South Carolina in Charleston.

But the researchers say they opted for Maryland because of its leadership and infrastructure, access to an increasing

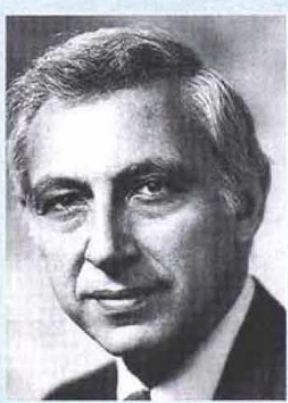

Gallo: keen to build links with clinicians. HIV-infected population, and the opportunity to combine basic research, epidemiological and intervention studies, and clinical service under one roof.

Gallo says he expects the link to the biotechnology company to enable the institute to move findings rapidly from basic research to the clinic. "I want to control what research is going on and move it toward practical applications," he says.

In addition to HIV, researchers at the institute will study leukaemia viruses, neural virology, herpes viruses, chronic hepatitis viruses, and perhaps eventually papillomaviruses.

Blattner says he welcomes the opportunity to bring together basic research and public health. "We're very committed to a clinical program that will serve a community where HIV is greatly expressed," he says. "We hope to develop a seamless interface between patient care and clinical research."

Nancy Touchette permit scientists engaged in basic research to use patented products and processes without restrictions and without being subject to licensing fees".

Others say they are alarmed by the broad implications of Roche's action. "Governments, universities and private institutions that pursue knowledge for its own sake and publish freely [must now worry about] whether every tool, every operation, every reagent, is under some patent," Arthur Kornberg, Nobel laureate and professor emeritus at Stanford University, said at a press conference called by Promega in San Francisco last week.

He cited various researchers who, he claimed, have received letters from Roche accusing them of patent violation. One group from North Carolina State University complained in a letter to Science in 1993 that Roche would not allow them to make their own enzyme even though they would not be able to continue their work.

But Ordonez claims that Linton's charges "do not accurately reflect US patent law". She also says that various disputes with university research groups had been settled "amicably", and that it was not Roche's policy to be concerned with researchers in individual laboratories.

At the same time, Ordonez declined to comment on whether Roche feels that the use of Taq for PCR by basic researchers should be exempt from the requirements of US patent law. "It's extremely complex," she said, suggesting that individual researchers consult with the licensing departments of their university or research institution about the situation. "I cannot speculate on everything that Hoffman LaRoche may do in the future."

The Taq controversy comes at a time of heated debate over whether patents on research tools are an inhibitory influence. Linton claims that his decision to stand up to Roche is based on a concern that they may be. "Promega would not be in business today if it was not for academic institutions," he said last week. "To turn our back on that would be to turn our back on the very source of innovation to which we owe our existence."

Roche sees the current issue differently. "If Promega were not conducting its illicit activities, the problem would not exist," says Ordonez.

Meanwhile, several of the researchers named on Roche's list say they were not concerned as long as Roche did not sue academics or their institutions - or tried to affect their work. "It just seems ridiculous to me," says Dennis Burton, of the Scripps Clinic and Research Foundation in La Jolla. "As researchers we do not look through catalogues to see who's got a patent on what."

Sally Lehrman \& David Dickson 